\title{
Agricultural History Review
}

(The journal of the British Agricultural History Society)

\section{Published since 1953}

The British Agricultural History Society serves as a forum for those interested in agricultural history and in the history of rural economy and society, irrespective of period and place. The society holds three conferences a year, in April, September and December. Its journal, The Agricultural History Review, distributed free to members, is published twice yearly, in March and September. Each issue contains five or six major articles, together with shorter items, bibliographical surveys, and an extensive and comprehensive book reviews section. In addition, the Society also publishes occasional supplements on topics of special interest. A consolidated index is available, covering all issues of the Review and supplements up to 1987.

The Society aims to foster innovation, as reflected in the contents of the Review.

Recent issues have included:

Supply Responsiveness in Dairy Farming: Some Regional Considerations

by Christine Hallas

Modest Growth and Capital Drain in an Advanced Economy: Dutch Agriculture

by Michael Wintle

The Origins and Early Development of the National Farmers' Union by Graham Cox, Philip Lowe and Michael Winter

Garden Seeds in England before the Late Eighteenth Century by Malcolm Thick

Northern Wolds and Wessex Downlands: Sheep Husbandry and FarmingPractice by G. G. S. Bowie

Flooding in Scania: a Method to Overcome Nutrient Deficiency by Urban Emanuelsson and Jens Möller

Dairywomen and Affectionate Wives: Women in the Irish Dairy Industry, 1890-1914

by Joanna Bourke

Sustainable Agriculture in the Middle Ages: the English Manor by J.N. Pretty

The Woodland Economy of Kent, 1066-1348 by K.P. Witney

Sand into Gold: the Evolution of the Foldcourse System in West Suffolk, 1200-1600 by Mark Bailey

Membership of the Society is open to all. The ordinary annual subscription is £15. A reduced subscription rate for students is available. Full details may be obtained from the Treasurer:

Dr E.J.T. Collins,

Institute of Agricultural History, University of Reading,

PO Box 229, Whiteknights,

Reading RG6 2AG. 


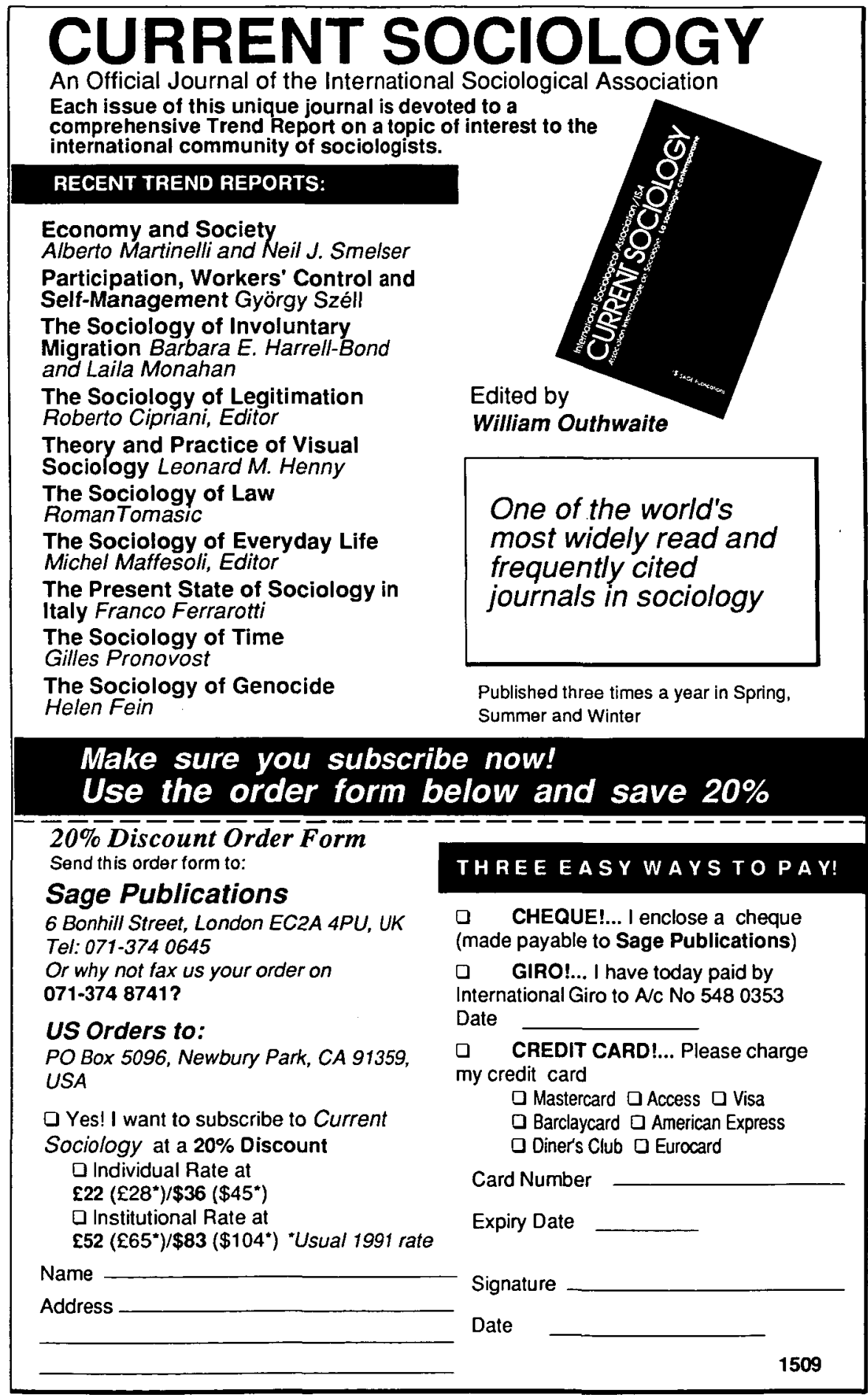




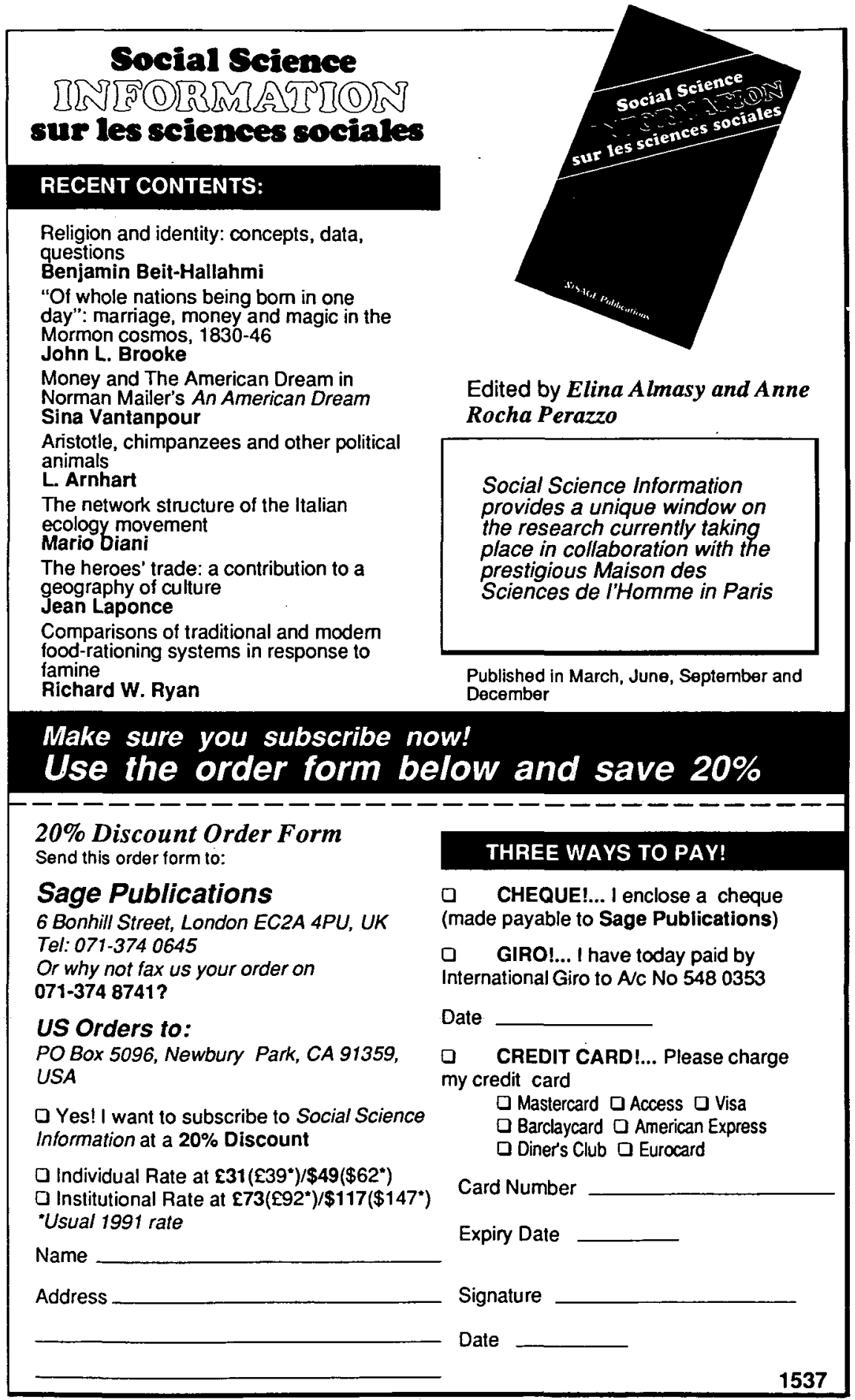



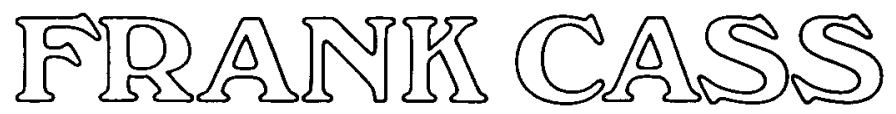

\section{THE JOURNAL OF PEASANT STUDIES}

\section{Editors T J Byres, Henry Bernstein and Tom Brass}

The Journal of Peasant Studies is one of the most pre-eminent journals in this multidisciplinary area of study. It is essential reading for all economists, historians, anthropologists, political scientists and sociologists who want to achieve a broader understanding of the role of peasants in political, economic and social change.

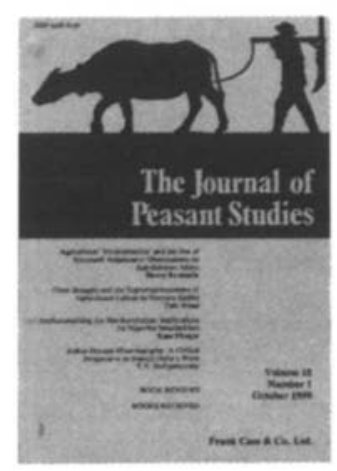

\section{Recent and forthcoming articles}

Agricultural 'Modernisation' and the Era of Structural Adjustment: Observations on Sub-Saharan Africa, Henry Bernstein Indian Peasant Historiography: A Critical Perspective on Ranajit Guha's Work, T.V. Sathyamurthy Agrarian Development, Family Farms and Sugar Capital in Colonial Taiwan, 1895-1945, Chih-Ming Ka

Gender Dimensions of Rural Poverty: Analysis from Bangladesh, Naila Kabeer

Quarterly: October, January, April, July ISSN 0306-6150

1991 subscription rates for Volume 18 Individuals \&38 (\$65) Institutions \&82 (\$135)

For your free sample copy of The Journal of Peasant Studies, please contact Frank Cass at the appropriate address below.

UK orders: Gainsborough House, 11 Gainsborough Road, London E11 1RS, UK Tel: (081) 530-4226 Fax: (081) 530-7795

US orders: c/o Allen Press, Inc., Subscription Services, PO Box 368, Lawrence, Kansas 66044, USA Tel: (913) 843-1235 


\section{Radical History Review}

Published for MARHO: The Radical Historians' Organization

Now published by Cambridge University Press, Radical History Review presents innovative scholarship and commentary that looks critically at the past and its historians from a non-sectarian perspective drawn from the political left. It scrutinizes conventional history and seeks to broaden and advance the discussion of crucial issues such as the role of race, class and gender in history. The journal offers original articles, review essays that examine the uses and abuses of history in the popular media, history museums and other public forums, and interviews with leading radical historians.

Each volume is illustrated with drawings, cartoons, photographs and other graphic art. Issues are often thematic and cover a wide range of geographic areas and subjects from sociology, politics, history and feminism to culture, literature, art and film. Recent themes have included: History from South Africa, The Women's Story, Film and History, Art and Ideology, and European Modernism.

\section{Subscription 1992}

Volumes 52-54: Winter, Spring and Autumn: $£ 31$ for institutions; $£ 17$ for individuals; $£ 15$ for students; airmail $£ 11$ per year extra ISSN 0163-6545

To subscribe, or for further information contact:

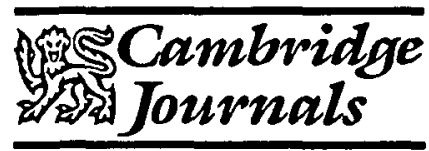

Cambridge University Press

The Edinburgh Building, Cambridge CB2 2RU, England

RUH $\quad 40$ West 20th St, New York, NY 10011-4211, USA 


\section{JOURNAL OF HISTORICAL SOCIOLOGY}

Edited by Philip Corrigan, Derek Sayer, Gavin Williams

The Journal of Historical

Sociology fills a major gap in the humanities and social sciences. Edited by a distinguished international panel of historians, anthropologists, geographers and sociologists, the journal is both interdiscplinary in approach and innovative in content.
Recent Articles include: Making Algeria French and Unmaking French Algeria David Prochaska Export Agriculture and Development Path: Independent Farming in Comparitive Perspective Mauricio A Font Making China 'Perfectly Equal' James L Hevia

\section{ORDER FORM - - - JOURNAL OF HISTOFICAL SOCIOLOGY}

Subscription Rates, Volume 4, 1991

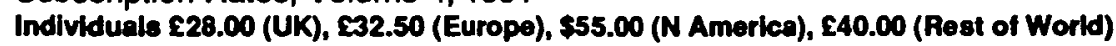

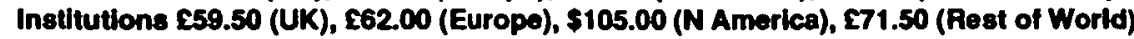
Published quarterly

$\square \quad$ Please enter my subscription/send me a sample copy

I I enclose a cheque/money order made payable to Basil Blackwell

D Please charge my Access/American Express/Diners Club/ Mastercard/Nisa account number

For payments via the National Girobank, the Basil Blackwell account humber is 2366053 Name

Address

Postcode

Signature Date

Payment must accompany orders

Please return this form to: Journals Marketing Manager, Basil Blackwell, 108 Cowley Road, Oxford OX41JF, England. Registered No. 180277. Or to: Journals Marketing Manager, Basil Blackwell, Three Cambridge Center, Cambridge, MA 02142. USA 
Articles or other materials for publication may be submitted to any one of the editors, whose addresses are given on the inside front cover. Contributors should submit two copies of articles, in double line spacing with reasonable margins, whether typed on A4 paper or computer printed. Articles should normally be no more than 8,000 words, but longer articles will be considered. An Abstract of about 150 words should also be supplied. Those generating articles on a computer or wordprocessor are invited to send a securely packed backup copy of their disk, with brief details of their machine, WP program used and density of disk. Alternatively a modem service is available. For fuller details please contact one of the editors.

S T Y L E

Contributors should aim for a style that is accessible to readers in related disciplines. Masculine forms used as universals, e.g. 'the archaeologist and his aspirations', should be avoided. Articles may be in either English or American spelling.

C I T A T I O N

Contributors may follow either of the standard conventions:

(a) in-text citations of sources; (b) citation in footnotes.

(a) In-text citation. Give author's surname, date of publication and page references (if any) in parentheses in the body of the text, e.g. '(Falassi, 1980b: 114)'. Where a second or subsequent work by a particular author in the same year is cited, references should be distinguished by letters (a, b, c, etc.) placed after the date. A complete list of references cited, arranged alphabetically by authors' surname, should be typed double-spaced at the end of the article in the form:

Falassi, A. 1980b. Folklore by the Fireside: Text and Context of the Tuscan Veglia (Austin, Texas).

Give place of publication, but not the publisher. Titles of books, articles and journals should be in the form of the examples in these Notes.

(b) Citation in footnotes. References should be given in notes, numbered consecutively through the typescript with raised numbers. Type the notes double-spaced on separate pages at the end of the article. Full publication details should be given at first mention, a short form thereafter:

John Barrell, The Dark Side of the Landscape: The Rural Poor in English Painting, 1730 - 1840 (Cambridge, 1980), p.89.

D Kramer (ed.), Critical Approaches to Hardy's Fiction (London, 1979), pp. 17-18.

B Reay, 'The last rising of the agricultural labourers: the battle in Bossenden Wood, 1838', History Workshop 26 (1988), 81-2.

Short forms:

Barrell, Dark Side, p. 90.

Kramer (ed.), Hardy's Fiction, pp. 175-6.

Reay, 'The last rising', p. 82.

Q U O T A T ION S

Quotations should be in single inverted commas, with double used only for quotations within quotations. Quotations of more than about five lines should be set off from the text and indented. Type double-spaced.

TA B LES A N D I LLUSTRATION S

Tables, graphs, maps and line drawings should be provided on separate sheets. Guidelines on presentation are included in the more detailed Notes for Contributors available from the editors. Contributors should provide full details of the illustration source and obtain permission to reproduce copyright material. Any necessary acknowledgement should be included in the caption.

P R O O F

Contributors will receive a proof of their article for correction of any printer's errors and any essential factual errors.

O F F P R I N T S

Twenty-five offprints of each contribution will be supplied, to be sent to the first named author in the case of jointly authored contributions. Further offprints may be purchased if ordered at 


\section{Rural History Economy, Society, Culture}

VOLUME 2 NUMBER 2 OCTOBER 1991

CONTENTS

Gabriel Cooney

Irish Neolithic Landscapes and Land Use Systems:

The Implications of Field Systems

Stephen Daniels and

Picturesque Landscaping and Estate Management:

Charles Watkins

Uvedale Price at Foxley, 1770 - 1829

Jenny Woodhouse

Tales From Another Country: Fictional Treatments of the Russian Peasantry, 1847 - 1861

Gaynor Kavanagh

Mangles, Muck and Myths: Rural History Museums in Britain

David Lowenthal

British National Identity and the English Landscape

Review Article

Andrew Charlesworth An Agenda for Historical Studies of Rural Protest in Britain, $1750-1850$

Notes and Queries

Reviews 